\title{
OIL OF THE SEEDS OF LUEFA CYLINDRICA
}

A. U. Umarov and A. L. Markman

Khimiya Prirodnykh Soedinenii, Vol. 4, No. 3, p. 187, 1968

Luffa cylindrica (suakwa vegetablesponge), family Cucurbitaceae is cultivated in the hot zones of the globe and, in the USSR, in the Caucasus, in the Crimea, and in the Central Asian republics.

The dimensions of the seeds are: length $12-14 \mathrm{~mm}$, breadth $6-7 \mathrm{~mm}$, thickness about $3 \mathrm{~mm}$; weight of 1000 seeds $110 \mathrm{~g}$. Ratio of the weight of the kernel to the weight of the husk $52: 48$. Oil content of the seeds (absolutely dry matter) $23.5 \%$, kernel $43.1 \%$. The seeds are rather bitter and on internal consumption act as a laxative.

The oil isolated from them is red with a greenish tinge. Specific gravity $\mathrm{d}_{4}^{20} 0.9204 ; \mathrm{n}_{4}^{20} 1.4785 ;$ viscosity $10.25^{\circ} \mathrm{E}$. Saponification no. $187.4 \mathrm{mg} / \mathrm{g}$; iodine no. 108.5 ; thiocyanogen number $66.85 \%$. Neutralization number of the fatty acids isolated from the oil 202.5; mean molecular weight 277. The mixtures of fatty acids have the following composition: palmitic $8.95 \%$, stearic $18.23 \%$, oleic $29.98 \%$, linoleic $47.10 \%$, dienoic $\mathrm{C}_{18}$ with conjugated double bonds $3.74 \%$.

Pigments present in the oil are $\gamma$-carotene and chlorophyll-b, and it contains $0.47 \%$ of phosphatides. The unsaponifiable fraction contains a crystalline substance with $\mathrm{mp} 142^{\circ} \mathrm{C}$ giving positive Sal'kovskii, Liebermann-Burchard, and Chugaev reactions for sterols [1].

\section{REFERENCE}

1. K. Bauer, Organic Analysis [Russian translation], Moscow, p. 432, 1953.

16 January 1968

Institute of the Chemistry of Plant Substances AS UzSSR

UDC 547.915

\section{THE OIL OF FRAXINUS SEEDS}

Z. Sabirov, A. U. Umarov, and A. L. Markman

Khimiya Prirodnykh Soedinenii, Vol. 4, No. 3, pp. 187-188, 1968

We have studied the oil of two species of ash growing in the Central Asian republics: Fraxinus pensylvanica (red ash) and F. lanceolata (green ash), family Oleaceae. There is information in the literature only on the oils of $F$. speciosa [1] and F. excelsior (European ash) [2].

\begin{tabular}{l|c|c|c|c}
\hline \multirow{2}{*}{ Index } & \multicolumn{2}{c|}{ Red ash } & \multicolumn{2}{c}{ Green ash } \\
\cline { 2 - 5 } & oil & $\begin{array}{c}\text { fatty } \\
\text { acids }\end{array}$ & oil & $\begin{array}{c}\text { fatty } \\
\text { acids }\end{array}$ \\
\hline Specific gravity, $d_{4}^{20}$ & 0.9247 & - & 0.9267 & - \\
$\begin{array}{l}\text { Refractive index, } n_{D}^{20} \\
\text { Viscosity, poise }\end{array}$ & 1.4820 & - & 1.4822 & - \\
Saponification no., mg/g & 0.5064 & - & 0.6080 & - \\
Iodine no., \% & 194.20 & - & 186.71 & - \\
Thiocyanate no., \% & 148.84 & 134.78 & 148.36 & 133.93 \\
Neutralization no., mg/g & 93.07 & 84.99 & 92.94 & 84.78 \\
Mean mol. wt. & - & 198.01 & - & 204.45 \\
Acetyl no., mg/g & 11.80 & - & 12.14 & - \\
Content of & Traces & - & Traces & - \\
$\quad \begin{array}{l}\text { Phosphatides } \\
\text { Unsaponifiables, \% }\end{array}$ & 19.87 & - & 12.14 & -
\end{tabular}

